\title{
Lidil
}

Revue de linguistique et de didactique des langues

\section{Making Adolescents' Diverse Communicative Repertoires Visible: A Creative Inquiry-Based Approach to Preparing Teachers to Work with (Im)migrant Youth}

Rendre visibles les divers répertoires communicatifs des adolescents :

une approche créative basée sur l'investigation pour former les enseignants à travailler avec les jeunes (im)migrants

\section{Gail Prasad}

\section{OpenEdition}

\section{Journals}

Electronic version

URL: http://journals.openedition.org/lidil/4867

DOI: $10.4000 /$ lidil.4867

ISSN: 1960-6052

\section{Publisher}

UGA Éditions/Université Grenoble Alpes

Printed version

ISBN: 978-2-37747-048-8

ISSN: $1146-6480$

\section{Electronic reference}

Gail Prasad, « Making Adolescents' Diverse Communicative Repertoires Visible: A Creative Inquiry-

Based Approach to Preparing Teachers to Work with (Im)migrant Youth », Lidil [Online], 57 | 2018,

Online since 01 May 2018, connection on 22 April 2019. URL : http://journals.openedition.org/

lidil/4867; DOl : 10.4000/lidil.4867

This text was automatically generated on 22 April 2019

(C) Lidil 


\section{Making Adolescents' Diverse Communicative Repertoires Visible: A Creative Inquiry-Based Approach to Preparing Teachers to Work with (Im)migrant Youth}

Rendre visibles les divers répertoires communicatifs des adolescents : une approche créative basée sur l'investigation pour former les enseignants à travailler avec les jeunes (im)migrants

Gail Prasad

\section{Introduction}

1 Linguistic diversity has become a defining feature of classrooms in the 21st century. An increasing number of students today speak different languages across the multiple spheres of their lives including home, school and wider society. Gregory and colleagues (2004) have examined how culturally and linguistically diverse (CLD) children tend to syncretize or integrate their language and literacy practices across their multiple, complex life worlds. Yet, despite the fact that research highlights the limits of monolingual approaches to teaching, students' cultural and linguistic repertoires have traditionally not been affirmed in classrooms (Cummins, 2001; García, Skutnabb-Kangas \& Torres-Guzmán, 2006). Souto-Manning (2012) argues that teachers can learn from their students' syncretic practices to develop more expansive conceptualizations of home and community language practices and literacies within their classrooms. This orientation aligns with the European development of pluralistic approaches to teaching and learning languages (Candelier \& De Pietro, 2012), and language awareness programs that draw 
teachers and students' attention to linguistic diversity both in society and within their own evolving and dynamic plurilingual repertoires.

In practice, however, mainstream classroom teachers across the US have often received little training to support English language learners (ELL) (Lucas, Villegas \& FreedsonGonzalez, 2008). Pettit's (2011) review of literature regarding teachers' beliefs about ELLs in mainstream classrooms identifies a "poverty of language learning" in US teacher education to the extent that "many teachers who have completed their degree have an overwhelming lack of knowledge of second language acquisition (SLA), multicultural education and $\mathrm{ESOL}^{1}$ pedagogy. In addition, many teachers have not learned a second language and therefore, cannot appreciate how difficult the experience can be" (p. 125). Over the past decade, there has been growing recognition of the need to incorporate critical multilingual language awareness (CMLA) into teacher education programs as a necessary foundation for teaching and learning in multilingual schools in the 21st century (Alim, 2005; García, 2015). In this article, I reflect on an initiative to integrate collaborative CMLA inquiry across a dual certification Masters teacher preparation program for secondary teachers as a strategy for expanding their critical multilingual language awareness and creative literacy practices in preparation for teaching in CLD schools. I begin by a synthetic review of the literature to teachers' and students' social representations of languages, creative identity investment, and CMLA as a framework for (re)designing the $\mathrm{ESL}^{2}$ certification sequence. I then present the reflexive language and literacy inquiry tools that teacher candidates (TCs) use first on themselves and then successively with learners across their teaching placements in order to develop greater understanding of adolescent communicative repertoires. I discuss the use of multiple approaches to engage TCs in thinking holistically about ELLs as complex language users rather than according to their language proficiency scores. Further, I reflect on challenges and possibilities for engaging TCs in language inquiry throughout their teacher certification and how the experience informs their understanding of students and themselves. Finally, I outline future directions of this work to continue to foster collaborative critical and creative language inquiry in schools.

\section{Towards critical and creative reflexivity: integrating social representations of languages, identity texts and critical language awareness}

\subsection{On social representations of languages}

3 Over the past two decades, literature published in French in the field of language education has drawn on Moscovici's (1961) theorization of social representations in French social psychology to analyse individuals' social representations of languages (Castellotti \& Moore 2002; Moore, 2001). Castellotti and Moore (2002) underscore that "representations [of language] play a crucial role in constructing identity, relationships with others and knowledge. [Social representations] are neither right nor wrong, and nor are they permanent; rather they enable individuals to categorize themselves and to decide which features they consider relevant in constructing their identity in relation to others" (p. 20). They argue that linguistic and cultural representations are an inherent part of language learning and as such need to be explicitly incorporated into language policies and teaching methods. Although an individual's social representations of 
languages are constructed discursively through diverse social experiences, they are manifest in the creation and/or modification of mental schema or images. Studies of language representation have traditionally employed discourse analysis to study how representations are produced in and through discursive practice individually and collectively (Bono \& Stratilaki, 2009; Gajo 2000; Jodelet, 1989; Py, 2004). With the emergence of pluralistic approaches to language learning and teaching, a variety of artsinformed practices have also been used to help learners make their implicit social representations of language and plurilingualism visible: for example, reflexive drawing (Molinié, 2009; Prasad, 2018b); photography (Farmer \& Prasad, 2014; Razafimandimbimanana, 2014); collage (Prasad, 2013, 2018a); theatre (Armand, Lory \& Rousseau, 2013). The diverse experiences and resources that teachers and students bring to their classrooms are revealed through multimodal representations of social representations of language make visible.

\subsection{On identity texts}

Scholarly literature published in English has tended to focus more heavily on teachers' explicit beliefs and attitudes towards languages and language learning rather than on social representations of languages (Gandara, Maxwell-Jolly \& Driscoll, 2005; Pettit, 2011; Reeves, 2006). Cummins (2001; Cummins \& Early, 2011) has advocated extensively for teachers to engage CLD students in the creative production of 'identity texts' as an instructional choice that showcases students' literacy expertise and supports literacy engagement by affirming the cultural and linguistic resources that minoritized immigrant students bring to their learning. Identity texts are creative academic projects in which students invest their identities by drawing on the full range of their cultural and linguistic repertoires. These projects are then said to function as mirrors to reflect students' identities back to them in a positive light. As students then share their identity texts with broad audiences, they receive positive affirmation of their cultural, linguistic and social identities.

5 To extend Cummins' initial conceptualization of identity text creation as a pedagogic strategy to foster students' investment of their CLD identities in academic work at school, I have argued that students' identity texts can also reveal learners' social representations of their own plurilingualism in transformative ways (Prasad, 2015; forthcoming). Furthermore, when learners from different language backgrounds work together in collaborative groups to create shared identity texts that reflect the range of their collective language and literacy resources, I argue that we can move beyond the metaphor of identity texts as mirrors towards a plural conceptualization of collaborative identity text projects as prisms that reflect and refract expansive language and literacy practices, as well as multiple identity options for diverse plurilingual learners in rich multilingual communities. Central to the creation of collaborative identity projects is a focus on cultivating students' critical multilingual language awareness as they encounter one another's language resources and creatively share their cultural and linguistic resources to collaboratively produce their multilingual identity text project. 


\subsection{On critical multilingual language awareness}

6 Since Hawkins' Awareness of Language Series-a group of pedagogical guides developed in the UK in the 1980s-, a number of language awareness programs have developed, particularly in francophone contexts including the European Socrates Lingua Programme EVLANG involving France, Austria, Spain and Italy as partners (Candelier, 2003) with the publication of teaching modules entitled Les langues du monde au quotidien (Kervan, 2013); the Swiss programme Éducation et ouverture aux langues à l'école (EOLE) (2003), and the Canadian venture Éveil au langage et ouverture à la diversité linguistique (ÉLODIL) (Armand \& Dagenais, 2005). These language awareness curriculae offer teachers thematic activities and units that lead students into explicit language inquiry drawing on languages that are largely unfamiliar to them, in order to expand all students' language awareness and appreciation of linguistic diversity. The development of plural approaches to language learning and teaching in Europe through the Framework of Reference for Pluralistic Approaches (FREPA) (2012) further elaborates and synthesizes ways to foster plurilingual and pluricultural competence through intercultural education, awakening to languages, intercomprehension of related languages and an integrated didactic approach to languages.

7 Teachers and students need not only to develop an awareness of linguistic diversity but also more critically, to recognize power relations associated with language and how they manifest themselves within the classroom, as well as in broader society. García (2015) in particular has called for pre-service teacher education programs to purposefully foster the critical multilingual language awareness of the teachers they prepare. She explains that in the 21st century, all teachers need:

[...] to have not only knowledge of the speakers of [diverse home] languages and their bilingualism (their knowledge of, and about, their languages and practices), but also of three additional factors: (1) the plurilingualism in their midst, (2) the histories of the speakers and their struggles, and (3) the social construction of the language of school in order to keep privilege in the hands of few. $(2015$, p. 7)

She further elaborates on how she has engaged prospective ESL and Bilingual education teachers in CMLA projects to deepen their understanding of children's diverse language and literacy practices. One example of such a project involves doing a descriptive review of a bilingual child's language practices and a critical sociolinguistic study of the linguistic landscape of urban schools.

CMLA seeks not only to raise awareness of linguistic diversity but also to equip teachers to become language and social activists. According to critical pedagogue Freire (2000):

Education either functions as an instrument which is used to facilitate the integration of the younger generation into the logic of the present system and bring about conformity or it becomes the practice of freedom, the means by which men and women deal critically and creatively with reality and discover how to participate in the transformation of their world. (p. 34)

He underscores the need for both critical and creative engagement in order to transform the monoglossic logic of the present system (which privileges standard English monolingualism) into a culturally and linguistically expansive paradigm that affirms teachers' and students' diverse communicative repertoires. Nieto (2000) has further pointed out that "the process of affirming the diversity of students begins first as a teacher's journey. A journey presupposes that the traveler will change along the way, and 
teaching is no exception" (p. 184). Indeed, the preparation of prospective teachers involves a journey first of be(com)ing aware of one's own language and literacy practices and one's social representations of languages, language speakers and language and literacy practices, in order to develop culturally responsive and linguistically expansive practice. In the context of the US, largely dominated by a monoglossic English (only) ideology, the journey of awakening to languages and linguistic diversity is not always comfortable for pre-service teachers, particularly for those who see themselves as monolingual Anglophones.

\section{Context}

11 In September 2015, the University of Wisconsin-Madison's School of Education welcomed its first cohort into a new intensive dual certification Masters program for secondary teachers in a content area such as Maths, Science, Social Studies or English Language Arts at the middle and high school levels, as well as in English-as-a-second language pedagogy. The first cohort could be divided roughly into three groups with respect to their initial interest in completing an ESL certification: 1) TCs who planned to become ESL teachers; 2) TCs who anticipated teaching in school districts with growing English learner populations; and 3) TCs with no prior interest in ESL licensure but who had enrolled in the program for other reasons, most notably, the program's intensive design which offers a dual-certification Masters in only 14 months. The range of TCs' interest in ESL prompted the development of a more explicit focus on CMLA. The goal of fostering TCs' CMLA was ultimately to help them understand their responsibility to develop equitable practice for all learners and for English Learners in particular. Building CMLA is a necessary precursor to developing culturally responsive and linguistically expansive practice.

12 Following from previous research engaging children as co-investigators of their lived plurilingualism, I sought to actively develop TCs' creative CMLA throughout the program by engaging with secondary students in collaborative CMLA inquiry. Drawing on the theory of social representation, the creative pedagogy of identity texts and the practice of developing CMLA, my goal was to foster TCs' reflexivity about their own communicative repertoires by (re)encountering themselves as language learners and be(com)ing teacherresearchers of language and literacy practices alongside their students.

When the second cohort began the program in June 2016, we introduced a new course into the ESL sequence: Foundations of Learning Second Languages and Literacies. The course introduced TCs to the components of language (phonology, morphology, syntax, semantics, etc.), approaches to literacy instruction and the concept and practice of CMLA. This course introduced two projects that continued throughout the ESL certification sequence: the first one engaged TCs in be(com)ing language learners themselves; the second one began to develop teachers as language and literacy researchers. For the first project, TCs were asked to invest in learning a new language for at least 20 hours over the academic year. Students were encouraged to pick a language that they did not already know nor had studied formally in order to experience and reflect on what it is like to be an early language learner. Students wrote reflective journal responses at the end of every five hours of language learning in which they made connections to the theory, methods and practices they were learning in their courses and to the feelings and experiences of English Learners in the field sites. 
The second project, and the focus of the remainder of this article, sought to raise TCs' CMLA by training them to become teacher-researchers investigating the language and literacy practices of adolescents. During the Foundations course, I introduced four creative and critical language and literacy inquiry tools: language portraits (Busch, 2017; Prasad, 2014), conversation maps (Dagenais \& Berron, 2001), language and literacy repertoire mapping via digital photography (Symthe \& Toohey, 2009; Prasad, 2013) and time-tracking of language practices. In the next section, I present each tool and illustrate its use with data generated by TCs from their initial use of the tools on themselves.

\section{Visualizing language and literacy inquiry tools}

\subsection{Language portraits}

15 In preparation for using each of the tools with students across their fieldwork sites, TCs practised using each tool on themselves and shared their artifacts with their colleagues. For the language portrait, TCs used a body silhouette to map their cultural and language biographies. They mapped each language and register onto their body maps by making a connection between how they used each language and each body part. For example, in fig. 1, teacher candidate Leah, puts Spanish on her brain in black because she associates it with learning Spanish for several years at school as a secondary student herself. She reflects:

When asked about my language and cultural identity, I wasn't sure how to explain until the crayons were placed in front of me. As I was asked to categorize my language and cultural characteristics with parts of my body, I found that the creative [nature] of the exercises forced me to dive deeper into what I considered my identity. During this activity I broke myself up into ten parts to which I strongly identify: English, Spanish, pop culture/music, White/Caucasian, family oriented, sports, education, kindness, humor and Massachusetts/East Coast. The colors flowed onto my portrait and each part of my individuality found a unique spot on my body. (Leah, Language Portrait Autobiography, p. 1)

Her reflection elaborates on metaphors she used to represent each of the aspects of her identity through different colors and on different parts of her body. She concludes that "completing this language portrait [...] had me consider features of myself that I have never thought about before" (Leah, Language Portrait Autobiography, p. 2). 
Figure 1. - Language portrait, Leah.

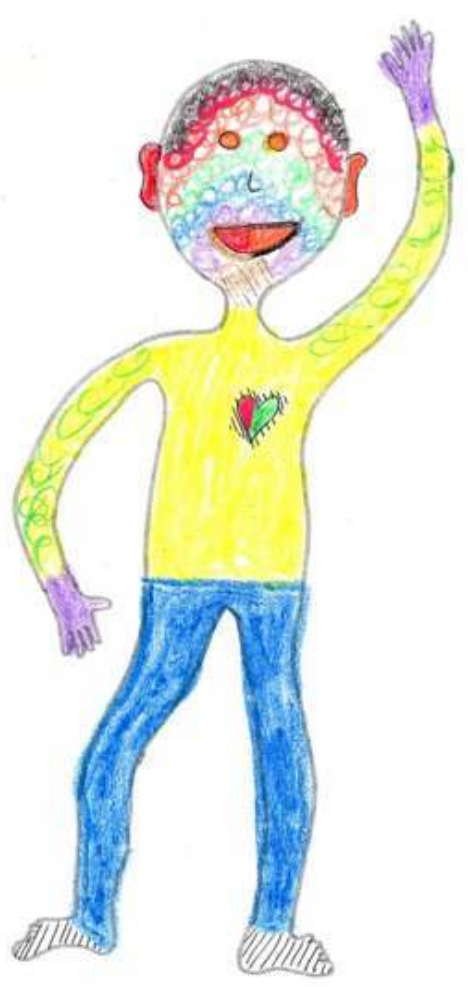

\subsection{Family and community language map}

17 For the second tool, a family and community language map, TCs wrote the names of family and friends that they communicate with around the outside of a large circle. I had extended Dagenais and Berron's (2002) family language map to give TCs the option of mapping conversation amongst friends rather than family only, as a large number of TCs were not living with family while enrolled at the university. TCs mapped with different colored lines the language(s) each person used to communicate with one another. 


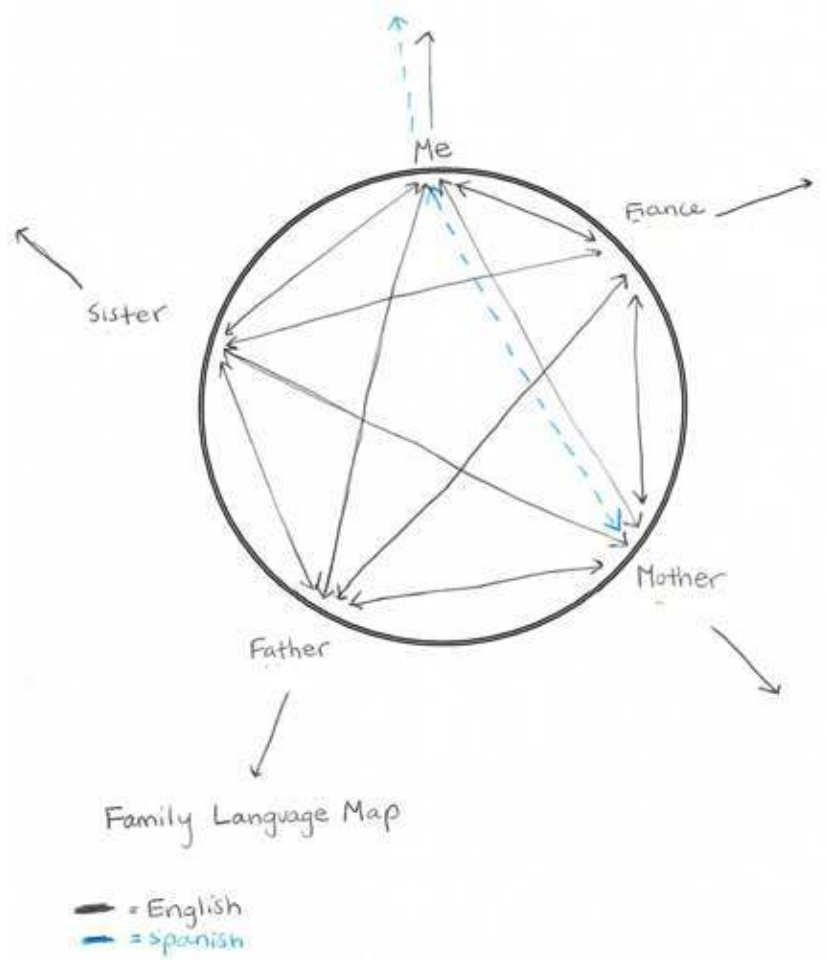

In her map (fig. 2), Leah included both her immediate family members, as well as her fiancé. She indicates not only the directionality of communication among her family members but also how each person communicates with others outside her family. In her reflection about her map, she notes:

I can speak very broken Spanish on occasion and I aspire to become more proficient as the Latina/o population increases in [this] area. I speak some Spanish with my mother because she too likes the language. She will say some things to me in Spanish such as "mi hija bonita" and I will also speak back to her. I am the only individual in my [family language] map that attempts to speak another language to others outside of my familial sphere. I have [substituted] in several bilingual classrooms and I have spoken some Spanish to students when it is clear that they did not understand me in English. (Family/Community Language Map Reflection, p. 1)

Leah's map represents visually her reflection on her home language practices (largely in English), as well as her own personal competence to draw on her knowledge of Spanish within her family with her mother and with Spanish-speaking students in schools.

Language portraits and conversation maps rely on self-reporting of language and literacy practices through reflexive drawing. By design, these visual language tools ask individuals to reflect on their language practices and to represent them visually as a way of entering into a conversation or biographical interview. These tools require little preparation on the part of the respondent; the data is his or her life experience. Similarly, little preparation is required on the part of the interviewer; a rough silhouette or a circle can easily be sketched on a piece of paper to engage a student in sharing his or her language background and experiences. 


\subsection{Language and literacy repertoire mapping via digital photography}

Repertoire mapping and time tracking require more attentive data collection on the part of the respondent. Language and literacy repertoire mapping requires respondents to document via digital photography everything that they read or write over the course of a day, but ideally, a weekday and a weekend day. TCs were not required to submit all of their photos, but used them to scaffold their reflection about their actual life language and literacy practices.

Leah created a chart to organize the practices she observed while photographing the latter over a 24-hour period. Table 1 depicts her chart. In addition, she created three photo collages to show samples of what she labeled academic, neutral and social languages and literacies. These artifacts reflect her initial construction of meaning and classification of her own language and literacy practices.

Table 1. - Leah's language and literacy practices over the course of one day.

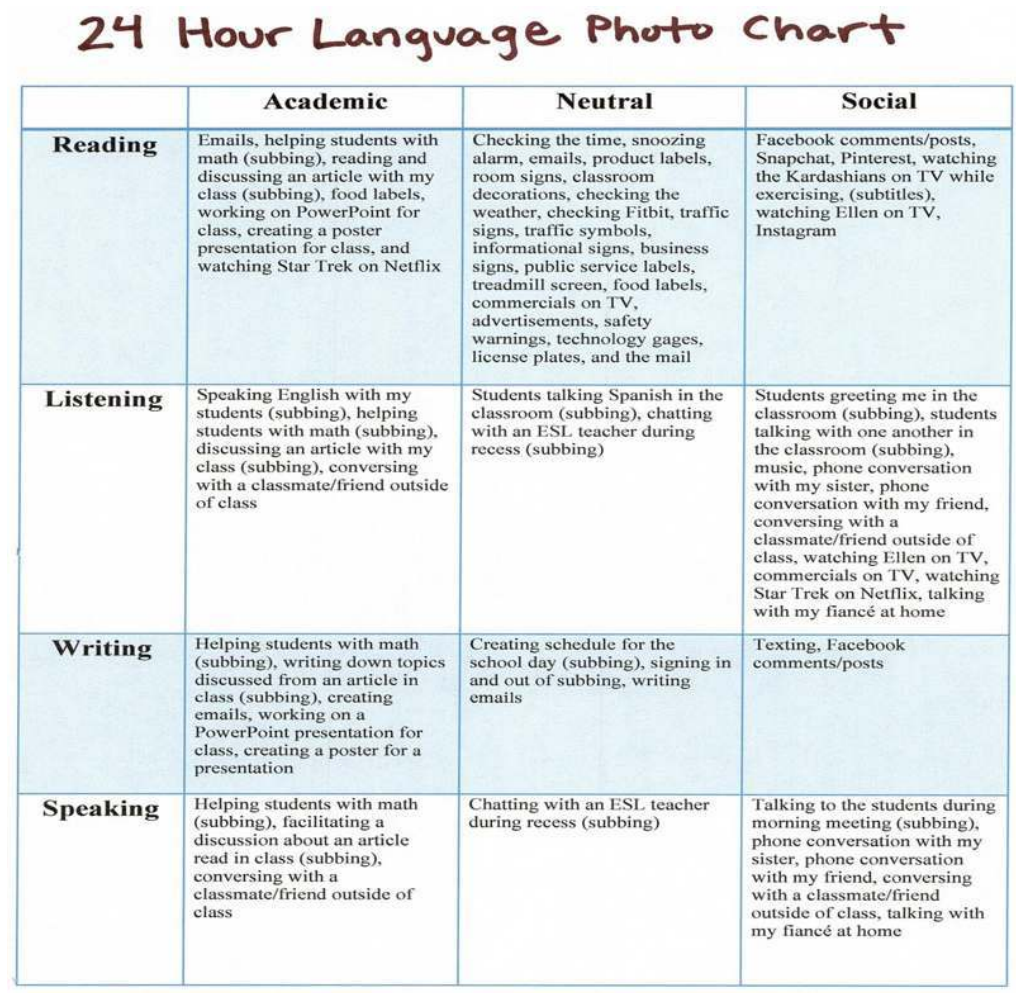

Across their written reflections and discussions with peers, TCs consistently found it surprising to discover through their photo data how much of their lives-both academically and socially-depends on their ability to read, write and communicate through language.

\subsection{Time tracking use of language registers and practices}

Finally, TCs tried to track more systematically how much time they spent using various registers and forms of language: for example, TCs naturally reported that they spent a lot 
of time using academic English because they were enrolled in a Masters teacher certification program. Over the course of an entire week, TCs kept a log about their language use practices. To make the process manageable, TCs completed a chart to record the amount of time they spent in each language, register or form of literacy. As a cohort, we identified five broad categories: school/academic language (in English); home language (with family, possibly in languages other than English); social language (with friends and colleagues, possibly in languages other than English); digital forms of communication (text messages, WhatsApp, Facebook, SnapChat, etc.); environmental print across an individual's linguistic landscape; and, an open category to be specified according to individual practice. Figure 3 shows Leah's records.

Figure 3. - Time tracking, Leah.

\begin{tabular}{|c|c|c|c|c|c|c|c|c|}
\hline \multicolumn{2}{|c|}{$\begin{array}{l}\text { Registers of Language } \\
\text { Weekly Time Tracking }\end{array}$} & Monday & Tuesday & Wednesday & Thursday & Friday & Saturday & Sunday \\
\hline \multirow{6}{*}{$\begin{array}{l}\text { Morning } \\
8 \mathrm{am}-12 \\
\text { noon }\end{array}$} & "School" English & $1: 55$ & $2 \mathrm{hr}$ & I hr & $O \mathrm{~min}$ & $O_{\min }$ & $O_{\text {min }}$ & $45 \mathrm{~min}$ \\
\hline & Home Language & Omin & $30 \mathrm{~min}$ & $30 \mathrm{~min}$ & $O_{\min }$ & $3: 30 \mathrm{hr}$ & $3: 30 \mathrm{hr}$ & $15 \mathrm{~min}$ \\
\hline & Social Language & $0 \mathrm{~min}$ & Omin & I hr & $2 h r$ & $0 \mathrm{~min}$ & 0 min & $0 \mathrm{~min}$ \\
\hline & Digital & $5 \mathrm{~min}$ & $30 \mathrm{~min}$ & $30 \mathrm{~min}$ & Ihr & $30 \mathrm{~min}$ & $0 \mathrm{~min}$ & Omin \\
\hline & Environmental & $5 \mathrm{~min}$ & $30 \mathrm{~min}$ & $30 \mathrm{~min}$ & $30 \mathrm{~min}$ & $0 \mathrm{~min}$ & $30 \mathrm{~min}$ & $2 h r$ \\
\hline & & $\begin{array}{l}\text { spanish } \\
1: 55 \\
\end{array}$ & $30 \mathrm{~min}$ & music $30 \mathrm{~min}$ & $30 \mathrm{~min}$ & $0 \mathrm{~min}$ & Omin & music int \\
\hline \multirow{6}{*}{$\begin{array}{l}\text { Afternoon } \\
12 \text { noon- } 4 \\
\text { pm }\end{array}$} & "School" English & $3: 00 \mathrm{hr}$ & $300 \mathrm{hr}$ & 3:00 hr & 1 hr & $0 \mathrm{~min}$ & Omin & min \\
\hline & Home Language & $20 \mathrm{~min}$ & Omin & 0 min & Omin & $4 h r$ & $2 h r$ & I hr \\
\hline & Social Language & $O \mathrm{~min}$ & Omin & $30 \mathrm{~min}$ & $2 h r$ & $O \min$ & $30 \mathrm{~min}$ & $3 h r$ \\
\hline & Digital & $20 \mathrm{~min}$ & $10 \mathrm{~min}$ & $15 \mathrm{~min}$ & $90 \mathrm{~min}$ & $0 \mathrm{~min}$ & 30 min & Omin \\
\hline & Environmental & $20 \mathrm{~min}$ & $20 \mathrm{~min}$ & Omin & $30 \mathrm{~min}$ & $O_{\text {min }}$ & $O \min$ & Omin \\
\hline & & $140 \mathrm{sic}$ min & musin & $15 \mathrm{~min}$ & musis $30 \mathrm{~min}$ & & $0 \min$ & Omin \\
\hline \multirow{6}{*}{$\begin{array}{l}\text { Early } \\
\text { Evening } \\
4 \text { pm - } \\
8 p m\end{array}$} & "School" English & 2:00hr & $200 \mathrm{hr}$ & $1: 30 \mathrm{hr}$ & $0 \mathrm{~min}$ & $O_{\text {min }}$ & $2 h r$ & $0 \mathrm{~min}$ \\
\hline & Home Language & 0 min & $1.00 \mathrm{hr}$ & $30 \mathrm{~min}$ & $0 \mathrm{~min}$ & Bhr & $1: 30 \mathrm{hr}$ & I hr \\
\hline & Social Language & $230 \mathrm{hr}$ & $0 \mathrm{~min}$ & $1: 15 \mathrm{hr}$ & $2 \mathrm{hr}$ & $O_{\min }$ & omin & $3 h r$ \\
\hline & Digital & $30 \mathrm{~min}$ & loohr & $10 \mathrm{~min}$ & $0 \mathrm{~min}$ & $0 \mathrm{~min}$ & $30 \mathrm{~min}$ & Omin \\
\hline & Environmental & $0 \mathrm{~min}$ & $O_{\text {min }}$ & $5 \mathrm{~min}$ & $0 \mathrm{~min}$ & $10 \mathrm{~min}$ & $0 \mathrm{~min}$ & $O \min$ \\
\hline & & Omin & $0 \mathrm{~min}$ & $30 \mathrm{~min}$ & $\frac{m w}{2} h r$ & music $50 \mathrm{him}$ & om & Omin \\
\hline \multirow{6}{*}{$\begin{array}{l}\text { Late } \\
\text { Evening } \\
\text { 8pm- } \\
\text { midnight }\end{array}$} & "School" English & $2 h r$ & $2 h r$ & $1 \mathrm{hr}$ & 1 hr & $O \min$ & $0 \mathrm{~min}$ & $3 \mathrm{hr}$ \\
\hline & Home Language & Omin & $1 \mathrm{hr}$ & $1 \mathrm{hr}$ & $2.30 \mathrm{hr}$ & $3 h r$ & 2:30hr & $30 \mathrm{~min}$ \\
\hline & Social Language & $30 \mathrm{~min}$ & 0 min & Ihr & $\sigma_{\min }$ & $30 \mathrm{~min}$ & $30 \mathrm{~min}$ & Omin \\
\hline & Digital & $30 \mathrm{~min}$ & I hr & $1 \mathrm{hr}$ & $30 \mathrm{~min}$ & $30 \mathrm{~min}$ & $1 \mathrm{hr}$ & $30 \mathrm{~min}$ \\
\hline & Environmental & $30 \mathrm{~min}$ & Omin & $0 \mathrm{~min}$ & Omin & $0 \mathrm{~min}$ & $0 \mathrm{~min}$ & Omin \\
\hline & & musil $30 \mathrm{~min}$ & 0 min & $0 \mathrm{~min}$ & Omin & omin & 0 min & 6 min \\
\hline
\end{tabular}

The time tracking was not intended necessarily to produce a reliable quantitative account of how each minute of the day is spent using language and literacy skills but rather to provide a snapshot of how various language and literacy practices make up an individual's experience over the course of a week. TCs rounded up time spent across different language and literacy practices and created a pie chart with weekly totals. Figure 4 shows how Leah graphically represented her data analysis. 
Figure 4. - Data visualization.

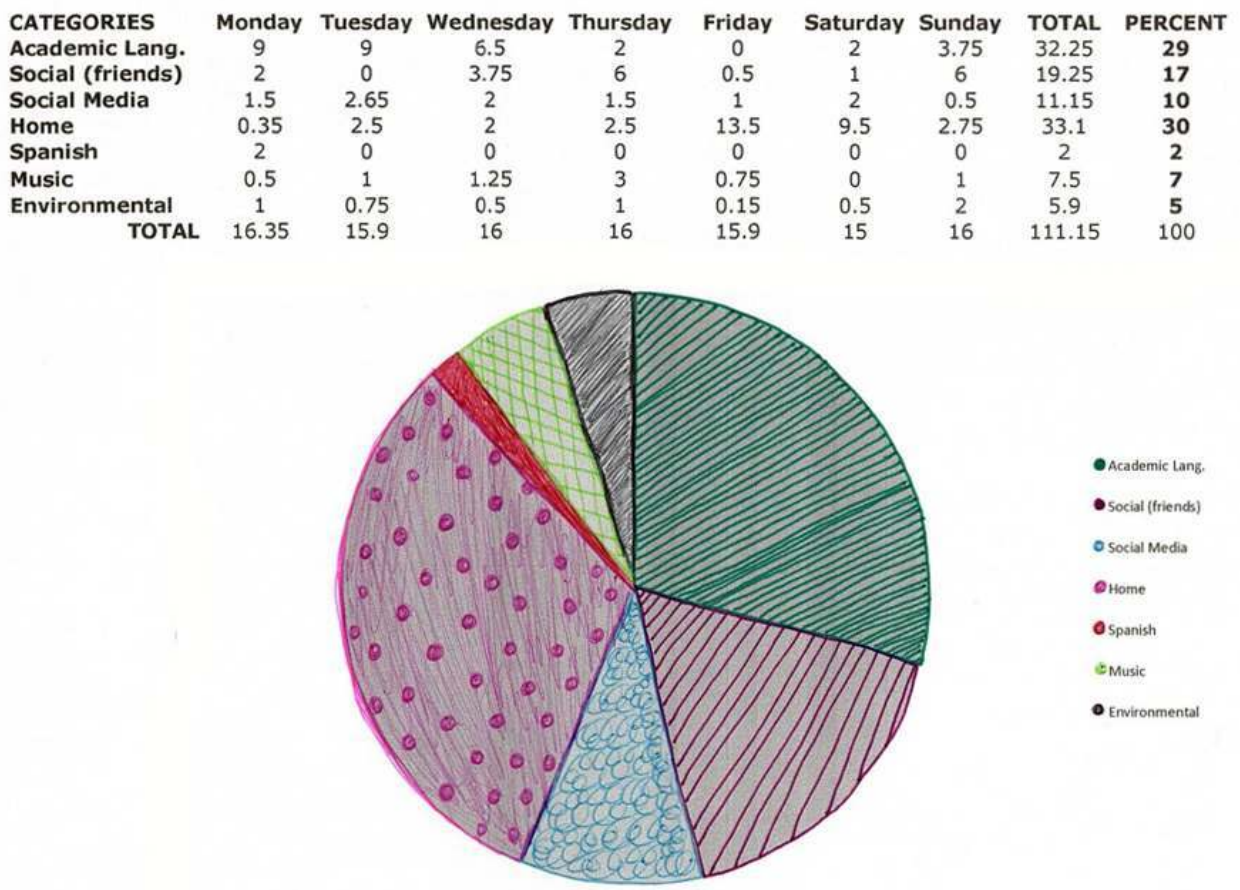

In comparing their graphs and those generated from data gathered with children and youth at their summer community placements, TCs observed similarities and differences across their graphic representations. These observations scaffolded meta-discussion about language and literacy practices among TCs. In essence, this data collection and visualization served to support TCs' talk about diverse language and literacy practices and their implications for teaching and learning in schools.

\section{On doing collaborative creative and critical language awareness inquiry in teacher education}

In this next section, I highlight three challenges of engaging TCs in creative and critical language awareness inquiry over the course of their teacher preparation program: administrative issues; TCs' preoccupation with getting the "right" answer; and, the time involved both on the part of the teacher candidate within the constraints of an intensive program, as well as for TCs' students.

\subsection{Challenge 1. - Administrative issues}

We encountered a number of administrative issues with engaging 56 TCs in collaborative, creative CMLA Inquiry. According to our Institutional Review Board for ethical research, all of the TCs had to complete an on-line course on research ethics in order to collect data from their students in their placement sites. In addition, research approvals had to be sought across the six school districts where TCs were completing their fieldwork. Ultimately, after applying to all six school districts, only two school districts granted research approval. As a result, TCs were allowed to collect data with willing students from their field sites as part of their teacher preparation but the data ultimately could not be 
saved for research purposes. While this outcome was disappointing, it gave TCs a firsthand view of the process of seeking ethical approval both at the university level, the level of the school district and at the individual school level as part of their graduate research training. As I sought to cultivate TCs' professional identities as teacher-researchers, the challenges we encountered while seeking various approvals raised important questions from the outset of their teaching careers about opportunities for teachers to engage in classroom-based research about their own practice.

\subsection{Challenge 2. - Teacher candidates' preoccupation with getting the "right" answer}

A second challenge that arose during the data collection phase was the sense of anxiety that many TCs expressed due to fears related to trying to recruit student participants. Furthermore, they feared that their students might not produce the "right" answers while generating research artifacts like the language portrait, the language map or their repertoire mapping. It felt risky to many TCs to carry out collaborative CMLA inquiry with students as part of their ESL coursework and fieldwork because they worried about how student responses would affect their final grades. Many TCs found it challenging to take on a teacher-as-researcher positionality, particularly at the beginning of the program because they were still in the process of developing their identities as teachers, whilst being students themselves.

\subsection{Challenge 3. - Development of understanding over time and through deliberate practice}

30 As TCs became more comfortable and confident in their identity as novice teachers, they also began to embrace the role of teacher-as-researcher. The challenge of intensive teacher education programs, however, is that time is limited. For TCs who were able to integrate the tools into their whole class instruction, the results were powerful. Following his implementation of language portraits and family language maps with his whole class almost a year after being introduced to the qualitative tools himself, Gabriel reflected:

Throughout both the collection of the data and their analysis, I found myself being exposed to identities that students carried meaningfully but that had never emerged in classroom talk. Typically, the awareness that I develop of students' personal proclivities and interests is the product of my inquiry in casual conversation or occasionally in small assignments. What I find beautiful and utilitarian about these tools, at once, is the open-endedness of the students' invitation to reflect and the power they bestow upon students to present themselves as they would like. The portrait and map silhouettes, bare in both artistic detail and instruction, provide students with an almost-blank slate on which they can write themselves with just enough direction that the data collected can be analysed and interpreted as a sum of individual data points... these points also carry enough nuanced information about each student to stand on their own as insightful glimpses into students as complex carriers of personal experiences, identities, and, of course, language repertoires. (MACRL data reflection, p. 1)

31 In an e-mail to me when he was submitting his final reflection, he noted, "the organization and analysis that went into the data made me feel that the portraits and maps have much more value for ESL teachers, and teachers in general, than I perceived at the end of our last summer term. It's been a rewarding experience" (Personal e-mail 
communication, 15 May 2017). Gabriel's note, along with his reflection, highlight how he came to realise that engaging with students in creative CMLA inquiry can be an effective strategy for understanding students' lives, identities and repertoires. Reflections such as these underscore the need for TCs to have multiple opportunities to try out tools on themselves and with their students, in order to recognize ways in which they might use them in their own practice.

Gabriel's reflection points to the benefits of engaging TCs in collaborative and creative CMLA inquiry as a foundational part of teacher education. Three main benefits emerged because we had included such inquiry throughout our teacher education program: first of all, TCs recognized the diversity of their own practices; secondly, they recognized the fullness of students' cultural and language assets; and thirdly, TCs recognized the academic language demands that learners face at school.

\subsection{Benefit 1. - Recognition of the diversity of one's own practices: developing a plurilingual mindset}

33 From the beginning of the dual certification program, TCs were introduced to Rymes' (2014) notion of communicative repertoires, which expands the concept of linguistic repertoires to also include the diversity of modes that individuals employ to communicate, including gesture and dress. The four tools discussed in this article served to visualize communicative repertoires. TCs initially used each tool on themselves as seen in Leah's examples. This initial phase of personal reflexive inquiry helped TCs to recognize the diversity of their own practices and to begin shifting from a monoglossic proficiency-oriented view towards a heteroglossic practice-based view of language. While many students identified themselves as monolingual Anglophones at the outset of their teacher education, the process of engaging in CMLA inquiry over the year served to help them recognize their multiple communicative resources.

\subsection{Benefit 2. - Recognition of students' multiple resources: developing a holistic view of students}

TCs consistently reported how having their students visualize their language and literacy practices helped them develop a holistic view of their students. At the end of the academic year, TCs shared student profiles they created based on the qualitative data students had generated using the language awareness inquiry tools. In teams, TCs compared and contrasted student profiles to reflect on the value of engaging students in CMLA inquiry. TCs repeatedly made observations similar to the following: "Language plays an integral role in students' home lives and yet many aspects [of home language and literacy practices] are not visible within the classroom." (Lisa, group discussion of data) As TCs analyzed student data in groups, their interactions not only supported the development of a holistic view of students but also more critically highlighted how students' identities and resources are often excluded from the school setting. This critical awareness is vital for novice teachers as they make decisions about how they will structure their classroom to support and/or constraint students' language and literacy practices. 


\subsection{Benefit 3. - Recognition of the academic language demands in schools: developing an appreciation of students' diverse literacy expertise}

TCs' analysis of student profiles further served to help them develop an appreciation of students' diverse literacy expertise. The creative CMLA inquiry tools served to help TCs become aware of their students' communicative repertoires. Through collaborative CMLA inquiry, TCs recognized the plurality of practices, experiences and resources that students bring to their learning. In turn, TCs were better prepared to creatively and critically mobilize students' assets for academic purposes.

\section{Future directions}

By way of conclusion, I point to future directions of this on-going inquiry. The challenges and benefits of engaging TCs in creative CMLA inquiry underscore the need for more research into additional tools. There is also a need for both analytical and pedagogical strategies that can amplify our understanding of students' and families' diverse language and literacy practices in the 21st century and of how we can mobilize their practices for academic purposes. I continue to follow TCs through our ESL certification in order both to refine the tools described in this article, as well as to develop additional ones. The tools presented here are a starting point for sustained discussion about the critical and creative role that diverse language practices and literacies play in teachers' and students' lives, and for suggesting ways and means of drawing on them to support academi, gain and social understanding of diversity.

\section{BIBLIOGRAPHY}

ALIM, Sammy. (2005). Critical Language Awareness in the United States: Revisiting Issues and Revising Pedagogies in a Resegregated Society. Educational Researcher, 34(7), 24-31.

ARMAND, Francoise \& DAGENAIS, Diane. (2005). Langues en contexte d'immigration : éveiller au langage et à la diversité linguistique en milieu scolaire. Revue de l'association des études canadiennes, numéro spécial printemps, 110-3.

ARmAnd, Francoise, LoRy, Marie-Paule \& Rousseau, Cécile. (2013). « Les histoires, ça montre les personnes dedans, les feelings. Pas possible si pas de théâtre » (Tahina) Ateliers d'expression théâtrale plurilingues en classe d'accueil. Lidil, 48, 37-55.

BONO, Mariana \& STRATILAKI, Sofia. (2009). The M-Factor, a Bilingual Asset for Plurilinguals? Learners' Representations, Discourse Strategies and Third Language Acquisition in Institutional Contexts. International Journal of Multilingualism, 6(2), 207-27. 
Busch, Brigitta. (2017). Biographical Approaches to Research in Multilingual Settings: Exploring Linguistic Repertoires. In M. Martin-Jones \& D. M. Martin (dir.), Researching Multilingualism: Critical and Ethnographic Perspectives (pp. 46-59). Abingdon: Taylor \& Francis.

CANDELIER, Michel (dir.). (2003). L'éveil aux langues à l'école primaire. Evlang : bilan d'une innovation européenne. Bruxelles: De Boeck-Duculot.

CANDELIER, Michel \& De PIETRo, Jean-François. (2012). FREPA: A Framework of Reference for Pluralistic Approaches to Languages and Cultures: Competences and Resources. Graz, Austria: European centre for modern languages (ECML).

CASTELlotTI, Véronique \& Moore, Danièle. (2002). Social Representations of Languages: Guide for the Development of Language Education Policies in Europe from Linguistic Diversity to Plurilingual Education. Strasbourg: Council of Europe.

Cummins, Jim. (2001). Negotiating Identities: Education for Empowerment in a Diverse Society (2nd ed.). Ontario: California Association for Bilingual Education.

CUMMINS, Jim \& EARLY, Margaret. (2011). Identity Texts: The Collaborative Creation of Power in Multilingual Schools. Stoke-on-Trent: Trentham Books.

DAgenais, Diane \& BERRON, Catherine. (2001). Promoting Multilingualism through French Immersion and Language Maintenance in Three Immigrant Families. Language, Culture and Curriculum, 14(2), 142-55.

FARMER, Diane \& PRASAD, Gail. (2014). Mise en récit de la mobilité chez les élèves plurilingues : portraits de langues et photos qui engagent les jeunes dans une démarche réflexive. Glottopol, 24, 80-98.

FREIRE, Paulo. (2000). Pedagogy of the Oppressed. London: Bloomsbury Publishing.

GAJO, Laurent. (2000). Disponibilité sociale des représentations : approche linguistique. Travaux neuchâtelois de linguistique (TRANEL), 32, 39-53.

GÁNDARA, Patricia, MAXWELl-Jolly, Julie \& DRISCOLL, Anne. (2005). Listening to Teachers of English Language Learners: A Survey of California Teachers' Challenges, Experiences, and Professional Development Needs. Santa Cruz, CA: Center for the Future of Teaching and Learning.

GARCíA, Ofelia. (2015). Critical Multilingual Language Awareness and Teacher Education. In J. Cenoz \& N. Hornberger (eds), Language Awareness and Multilingualism, Encyclopedia of Language and Education (pp. 1-17). London: Springer International Publishing.

GARCíA, Ofelia, SKUTNABB-KANGAS, Tove \& TORRES-GuZMAN, Maria (dir.). (2006). Imagining Multilingual Schools: Language in Education and Glocalization. Toronto: Multilingual Matters.

Gregory, Eve, LonG, Susi \& VolK, Dinah (dir.). (2004). Many Pathways to Literacy: Young Children Learning with Siblings, Grandparents, Peers, and Communities. New York: Routledge Falmer.

JODELET, Denise. (1989). Représentations sociales : un domaine en expansion. In D. Jodelet (dir.), Les représentations sociales (pp. 47-78). Paris: PUF.

KERVAN, Martine (dir.). (2013). Les langues du monde au quotidien. Rennes: SCEREN, CRDP.

LuCAS, Tamara, VILlegas, Ana Maria \& FREEDSON-GonZALEZ, Margaret. (2008). Linguistically Responsive Teacher Education: Preparing Classroom Teachers to Teach English Language Learners. Journal of Teacher Education, 59(4), 361-73.

NiETO, Sonia. (2000). Placing Equity Front and Center: Some Thoughts on Transforming Teacher Education for a New Century. Journal of Teacher Education, 51(3), 180-87. 
MoLINIÉ, Muriel (dir.). (2009). Le dessin réflexif: élément pour une herméneutique du sujet plurilingue. Cergy-Pontoise: Centre de recherche Textes et Francophonies.

MOORE, Danièle. (2001). Les représentations des langues et de leur apprentissage : références, modèles, données et méthodes. Paris: Didier.

Moscovici, Serge. (1961). La psychanalyse, son image et son public. Paris: Presses universitaires de France.

Pettit, Stacie. (2011). Teachers' Beliefs about English Language Learners in the Mainstream Classroom: A Review of the Literature. International Multilingual Research Journal, 5(2), 123-47.

PRASAD, Gail. (2013). Children As Co-ethnographers of Their Plurilingual Literacy Practices: An Exploratory Case Study. Language and Literacy, 15(3), 4-30.

PRASAD, Gail. (2014). Portraits of Plurilingualism in a French International School in Toronto: Exploring the Role of Visual Methods to Access Students' Representations of Their Linguistically Diverse Identities. Canadian Journal of Applied Linguistics / Revue canadienne de linguistique appliquée, 17(1), 51-77.

PRASAD, Gail. (2015). Beyond the Mirror towards a Plurilingual Prism: Exploring the Creation of Plurilingual "Identity Texts" in English and French Classrooms in Toronto and Montpellier. Intercultural Education, 26(6), 497-514. <http://dx.doi.org/10.1080/14675986.2015.1109775>.

PRASAD, Gail. (2018a). “How Does It Look and Feel to Be Plurilingual?”: Analysing Children's Representations of Plurilingualism through Collage. International Journal of Bilingual Education and Bilingualism. <https://doi.org/10.1080/13670050.2017.1420033>.

PRASAD, Gail. (2018b). “But Do Monolingual People Really Exist?” Analysing Elementary Students' Contrasting Representations of Plurilingualism through Sequential Reflexive Drawing. Language and Intercultural Communication. <https://doi.org/10.1080/14708477.2018.1425412>.

Py, Bernard. (2004). Pour une approche linguistique des représentations sociales. Langages, 154, 619.

RAZAFIMANDIMBIMANANA, Elantina. (2014). Quelque part entre des inaccessibles : une façon de penser la photographie et le sens en sociolinguistique. Glottopol. Revue de sociolinguistique en ligne, $23,47-66$

REEVES, Jenelle. (2006). Secondary Teacher Attitudes toward Including English-Language Learners in Mainstream Classrooms. The Journal of Educational Research, 99(3), 131-43.

Souto-MAnNing, Mariana. (2012). Teacher As Researcher: Teacher Action Research in Teacher Education. Childhood Education, 88(1), 54-6.

Smythe, Suzanne \& Toонey, Kellen. (2009). Investigating Sociohistorical Contexts and Practices through a Community Scan: A Canadian Punjabi-Sikh Example. Language and Education, 23(1), 3757.

\section{NOTES}

1. ESOL - English to Speakers of Other Languages.

2. ESL - English-as-a-Second-Language. 


\section{ABSTRACTS}

This article reflects on an on-going initiative to integrate collaborative, creative, and critical language awareness inquiry across a dual certification teacher preparation Masters program for secondary pre-service teachers in Wisconsin, USA. This teacher-as-researcher programmatic design seeks to expand teacher candidates' critical multilingual language awareness and creative literacy practices in preparation for teaching in culturally and linguistically diverse schools. Drawing on theories of social representation, identity investment and critical language awareness, this article examines the use of a variety of creative approaches to engage teacher candidates reflexively in thinking holistically about themselves and their students as language actors rather than according to fixed language proficiency scores.

Cet article rend compte d'une recherche collaborative, menée au sein d'un programme de maitrise menant à une double certification en didactique disciplinaire et en anglais langue seconde à l'école secondaire dans l'État du Wisconsin (États Unis). Cette recherche a été implantée afin de soutenir le développement chez les futurs enseignants d'une conscience plurilingue critique, pour les encourager à adopter des pratiques créatives de littératie ainsi que pour les préparer à l'enseignement dans des écoles culturellement et linguistiquement diverses. S'appuyant sur les théories des représentations sociales sur les langues, de l'investissement identitaire et de l'éveil aux langues critique, cet article examine les approches plurielles et créatives comme outil pour engager les étudiants en formation des maitres à réfléchir de manière holistique sur eux-mêmes et leurs élèves en tant qu'êtres langagiers plutôt que selon leurs résultats scolaires en termes de compétences linguistiques.

INDEX

Keywords: social representations, identity, language awareness, teacher-as-researcher, communicative repertoire

Mots-clés: représentations sociales, identité, éveil aux langues, approches plurielles, syncrétisme, répertoire langagier

\section{AUTHOR}

\section{GAIL PRASAD}

University of Wisconsin-Madison 